\title{
Revealing the antimicrobial and enzymatic potentials of culturable fungal endophytes from tropical pitcher plants (Nepenthes spp.)
}

\author{
Lee JM, Tan WS and Ting ASY*
}

School of Science, Monash University Malaysia, Jalan Lagoon Selatan, Bandar Sunway, 46150 Petaling Jaya, Selangor, Malaysia.

Lee JM, Tan WS, Ting ASY 2014 - Revealing the antimicrobial and enzymatic potentials of culturable fungal endophytes from tropical pitcher plants (Nepenthes spp.). Mycosphere 5(2), 364 377, Doi 10.5943/mycosphere/5/2/10

\begin{abstract}
In recent years, fungal endophytes from diverse host species have been extensively studied for valuable compounds (enzymes, antimicrobial compounds). Investigations on fungal endophytes from tropical Nepenthes spp. are however limited, despite hosting a wide range of macro- and microorganisms. In this study, we explored fungal endophytes from N. ampullaria and N. mirabilis for enzymatic and antimicrobial potential. A total of 26 isolates were obtained and they demonstrated a variety of enzymatic activities, mostly producing cellulase, chitinase, lipase and Lasparaginase. These endophytes also have antifungal activity. Sequencing results on 12 selected isolates revealed a diverse endophytic community, comprising mainly of the species complex of Colletotrichum gloeosporioides (and its teleomorph Glomerella) (3 isolates), Phomopsis sp. (2 isolates), Trichoderma asperellum, Penicillium simplicissimum and Aspergillus terreus. Several uncommon species were also revealed-Lasiodiplodia, Isaria, Sarcosomataceae and a yeast-like fungi Meyerozyma guilliermondii. We revealed the diversity and the novel profiling of enzymatic and antimicrobial potential of endophytes from Nepenthes.
\end{abstract}

Key words - antibacterial - antifungal - enzymes - Nepenthes ampullaria - Nepenthes mirabilis

\section{Introduction}

Fungal endophytes are defined as fungi that during any of their growth stages, asymptomatically colonize the internal tissues or organs of plant. They are found ubiquitously in various plants; from mosses and ferns to various gymnosperms and angiosperms (Arnold \& Lutzoni 2007, U'Ren et al. 2012), including aquatic plants ( $\mathrm{Li}$ et al. 2010). Their ability to co-exist and coevolve with host plants is attributed to the balance achieved between the virulence of endophytes and the host's defenses (Schulz et al. 2006). In this symbiotic relationship, fungal endophytes receive 'shelter' and nutrients from the hosts while the hosts benefit from an array of beneficial attributes (White et al. 2002, Debbab et al. 2012) which include safeguarding against natural enemies of plants such as pathogens and herbivores (Tintjer \& Rudges 2006, Vega et al. 2008; Singh et al. 2011); supporting plant growth through the production of phytohormones (Hamayun et al. 2010, Hoffman et al. 2014); and increasing the resistance of plant to multiple stresses such as salinity and heavy metal toxicity in soil (Rodriguez et al. 2008, Deng et al. 2011, Khan et al. 2014). 
In recent years, fungal endophytes have been explored for diverse applications. This is attributed to the vast range of valuable compounds produced such as enzymes and secondary metabolites. Chitinase, lipase and cellulase are common enzymes produced by various fungal endophytes such as Beauveria, Lecanicillium, Metarhizium and Trichoderma, which contribute to their role in control of pest and diseases (Fang et al. 2005, St Leger \& Wang 2010, Sandhu et al. 2012). Explorations of other enzymes such as asparaginase (Theantana et al. 2007, Thirunavukkarasu et al. 2011) and tyrosinase (Mandyam et al. 2010) have recently been intensified due to their valuable anticancer (anti-leukemia agent) (Appel et al. 2007) and medicinal value (treatment of Parkinson's disease, myocardial disease) (Raju et al. 1993). Hydrolytic enzymes (amylase, cellulase and laccase) with various industrial applications are also of major interest. Although hydrolyases are typically isolated from soil-borne Aspergillus, Penicillium and Rhizopus spp. (Pandey et al. 2000), endophytes producing these enzymes present an interesting alternative. In addition to enzymes, various secondary metabolites with antibacterial (Gunatilaka 2006, Ahmed et al. 2011, Praptiwi et al. 2013), anti-inflammatory (Zhang et al. 2014); anticancer (Hazalin et al. 2009, Mohana 2012), antituberculosis (Gordien et al. 2010) and antimalarial (Elfita et al. 2011) activities have been identified. Endophytes have also showed potential in the agriculture sector as plant growth promoters (Silva et al. 2012, Chujo and Scott 2014, Islam et al. 2014) and biocontrol agents (Li et al. 2008, Silva et al. 2012, Kusari et al. 2012).

In this study, the host plant of interest is the tropical pitcher plant, Nepenthes spp. or also known as "monkey cups". We selected this atypical host plant and explored the potential of the endophytes they harbor. Pitcher plants are interesting hosts of endophytes as they grow in hostile environments (in soils low in $\mathrm{pH}$ and nutrients); relying heavily on nutrient input from captured and digested prey in their pitchers (Mohan and Clarke, 2010). Digestion of prey is regulated by proteases (Athauda et al. 2004), lipases (Tokes et al. 1974), ribonucleases (Stephenson \& Hogan 2006), and chitinases (Eilenberg et al. 2006). It is however, not known if the endophytes may have a role in secreting these extracellular enzymes although microbial-deriving lipase, acid phosphatase, glucosidase and glucosaminidase, have been detected in the fluids of the pitcher (Morohoshi et al. 2011, Takeuchi et al. 2011). Hence, pitcher plants are worthy alternative host plants to isolate beneficial fungal endophytes. For this study, we isolated fungal endophytes from pitchers and leaves of $N$. ampullaria and $N$. mirabilis and screened the endophytes for production of various enzymes and antimicrobial potential. Endophytes demonstrating strong enzymatic and antimicrobial activities were further identified by DNA sequencing of the internal transcribed spacer (ITS) region using universal primers of ITS1 and ITS4 to reveal their most probable identity. Our results here are novel; highlighting endophytes from unexplored host plants, the discovery of some uncommon endophyte species, and the documentation of their enzymatic and antimicrobial potential.

\section{Materials \& Methods}

The chemicals, media and reagents used were products from various manufacturers and they are listed as the following, $\mathrm{MgSO}_{4} .7 \mathrm{H}_{2} \mathrm{O}, \mathrm{FeSO}_{4} .7 \mathrm{H}_{2} \mathrm{O}, \mathrm{MnSO}_{4} .7 \mathrm{H}_{2} \mathrm{O}$ and $\mathrm{K}_{2} \mathrm{HPO}_{4}$ from Systerm; starch, Na-carbox ymethyl cellulose (CMC), 1-napthol, Lactophenol Lotton Blue (LCB), potassium sodium tartarate, $\mathrm{CuNO}_{3} .5 \mathrm{H}_{2} \mathrm{O}, \mathrm{ZnSO}_{4} .7 \mathrm{H}_{2} \mathrm{O}$ and $\mathrm{CaCl}_{2} .2 \mathrm{H}_{2} \mathrm{O}$ from $\mathrm{R} \& \mathrm{M}$ Chemicals; chitin, Congo Red, N-acetylglucosamine (NAGA), L-asparagine, 2,2-azino-bis(3ethylbenzothiazoline)-6-sulphonic acid (ABTS) and $\mathrm{NaCl}$ from Sigma; Potato Dextrose Agar (PDA), Nutrient Agar (NA), Tween 20, $\mathrm{KCl}$ and $\mathrm{NaNO}_{3}$ from Merck; phenol red, glycine and $\mathrm{K}_{2} \mathrm{HPO}_{4}$ from Riendemann Schmidt; dinitrosalicylic acid (DNS) from Fluka; glucose from Kollin Chemicals; yeast extract from Becton, Dickson and Company; peptone from Lab M; agar powder from SRL Chemicals; and p-cresol from SAFC.

\section{Isolation of endophytes}

The pitchers and leaves of $N$. ampullaria and N. mirabilis were collected from Sungai Chilling waterfall in Selangor, Malaysia (3.599N 101.736E). The plant samples were surfacesterilized using the triple sterilization technique. Briefly, the plant tissues were sequentially 
immersed in $95 \%$ ethanol $(1 \mathrm{~min})$, followed by $3.25 \%$ sodium hypochlorite (10 min) and finally 95\% ethanol $(30 \mathrm{sec})$, prior to rinsing with sterile distilled water (three times). The surfacesterilized tissues were then blot-dried, cut into smaller-sized segments $\left(\sim 1 \times 1 \mathrm{~cm}^{2}\right)$ and placed onto Potato Dextrose Agar (PDA). All culture plates were incubated at $25 \pm 2^{\circ} \mathrm{C}$, with pure cultures subsequently established by culturing onto fresh PDA plates.

\section{Screening for valuable enzymes from endophytes}

Endophytes were screened for their production of amylases, cellulases, asparaginases, laccases, lipases, tyrosinases and chitinases. To detect amylase activity, a $0.5 \mathrm{~cm}$ mycelial plug of the endophyte was inoculated onto Glucose Yeast Extract Peptone (GYP) agar $(1 \mathrm{~g}$ glucose, $0.1 \mathrm{~g}$ yeast extract, $0.5 \mathrm{~g}$ peptone, $16 \mathrm{~g}$ agar and $1 \mathrm{~L}$ of distilled water; $\mathrm{pH} 6$ ) supplemented with $2 \%$ soluble starch, and incubated for 5 days at $25 \pm 2{ }^{\circ} \mathrm{C}$. After incubation, the agar plate was overlaid with $1 \%$ iodine ( $2 \%$ potassium iodide). Amylase activity was confirmed by the formation of halo zone around the colony in an otherwise blue medium (Maria et al. 2005). Cellulase activity was detected by inoculating on GYP agar supplemented with $0.5 \%$ of CMC, in which after incubation, was overlaid with $0.2 \%$ aqueous Congo Red $(15 \mathrm{~min})$ and destained with $1 \mathrm{M} \mathrm{NaCl}$ for another 15 min. Formation of halo zone indicate cellulase activity (Maria et al. 2005). Similarly, tyrosinase activity was detected by inoculating on GYP agar and after incubation, was overlaid with a mixture of $0.11 \%$ p-cresol and $0.05 \%$ glycine and left for $24 \mathrm{~h}$. The appearance of a reddish-brown zone around the colony indicated positive tyrosinase activity (Maria et al. 2005).

Chitinase activity was detected by inoculating on chitin-based media $\left(1 \mathrm{~g} \mathrm{KH}_{2} \mathrm{PO}_{4}, 0.5 \mathrm{~g}\right.$ $\mathrm{MgSO}_{4} .7 \mathrm{H}_{2} \mathrm{O}, 0.5 \mathrm{~g} \mathrm{KCl}, 2 \%$ agar, $0.5 \%$ crude chitin, and $1 \mathrm{~L}$ of distilled water, $\mathrm{pH} 5.5$ ) (Sharaf $e t$ al. 2012) and incubated at $25 \pm 2^{\circ} \mathrm{C}$ for 10 days. Isolates with chitinolytic activity grew on the agar while no growth indicates absence of chitinase activity as compared to the positive control using Serratia marcescens (Okay et al. 2008). Asparaginase activity was detected by inoculating onto modified Czapek Dox Agar (2 g glucose, $10 \mathrm{~g} \mathrm{~L}$-asparagine, $1.52 \mathrm{~g} \mathrm{KH}_{2} \mathrm{PO}_{4}, 0.52 \mathrm{~g} \mathrm{MgSO} 4.7 \mathrm{H}_{2} \mathrm{O}$, $0.52 \mathrm{~g} \mathrm{KCl}, 0.01 \mathrm{~g} \mathrm{FeSO}_{4} .7 \mathrm{H}_{2} \mathrm{O}, 0.03 \mathrm{~g} \mathrm{CuNO}_{3} .5 \mathrm{H}_{2} \mathrm{O}, 0.05 \mathrm{~g} \mathrm{ZnSO}_{4} .7 \mathrm{H}_{2} \mathrm{O}, 20 \mathrm{~g}$ agar, $1 \mathrm{~L}$ distilled water) supplemented with $3 \mathrm{~mL}$ of phenol red (pH 6.2). After incubation, the formation of a pink zone around the colony in an otherwise yellow medium indicates asparaginase activity (Thirunavukkarasu et al. 2011). Laccase activity was assessed by inoculating on GYP agar supplemented with $0.005 \%$ 1-napthol $(\mathrm{pH} 6)$ and incubated at $25 \pm 2^{\circ} \mathrm{C}$ for 5 days. Positive laccase activity was ascertained when a purple zone appears around the colony as a result of the oxidation of 1-napthol, on an otherwise clear agar (Maria et al. 2005). For lipase activity, mycelial plugs were inoculated onto peptone agar medium (10 g peptone, $5 \mathrm{~g} \mathrm{NaCl}, 0.1 \mathrm{~g} \mathrm{CaCl}_{2} .2 \mathrm{H}_{2} \mathrm{O}, 16 \mathrm{~g}$ agar, $1 \mathrm{~L}$ distilled water; $\mathrm{pH}$ 6) supplemented with Tween 20 (separately filter sterilized, $1 \mathrm{~mL}$ to $100 \mathrm{~mL}$ medium) and incubated at $25 \pm 2{ }^{\circ} \mathrm{C}$ for 5 days. Lipase activity was confirmed with the detection of insoluble calcium crystal complex precipitates around the colony, as a result of the binding of liberated fatty acids with the calcium in the agar (Maria et al. 2005). For all enzyme activities, the diameters of the halo zones (or coloured zones in some assays) were measured and compared against the colony diameter to obtain the ratio of colony diameter to enzyme production

(Bhagobaty \& Joshi 2012).

\section{Activities of key enzymes by selected endophytes}

The activities of three key enzymes; amylase, cellulase and chitinase, were further determined quantitatively as these enzymes are related to their ability to colonize host-plants (amylase, cellulase) and their antifungal potential (chitinase). To initiate amylase assay, $25 \mathrm{~mL}$ of culture broth $\left(3 \mathrm{~g} \mathrm{NaNO}_{3}, 1 \mathrm{~g} \mathrm{KH}_{2} \mathrm{PO}_{4}, 0.5 \mathrm{~g} \mathrm{MgSO}_{4} .7 \mathrm{H}_{2} \mathrm{O}, 5 \mathrm{~g} \mathrm{KCl}, 0.01 \mathrm{~g} \mathrm{FeSO}_{4} .7 \mathrm{H}_{2} \mathrm{O}, 0.1 \mathrm{~g}\right.$ $\mathrm{CaCl}_{2} .2 \mathrm{H}_{2} \mathrm{O}, 15 \mathrm{~g}$ starch, $1 \mathrm{~L}$ sterile distilled water) was first inoculated with a $0.5 \mathrm{~cm}$ mycelial plug and incubated at $25 \pm 2^{\circ} \mathrm{C}$ for 7 days. The culture was then centrifuged (5000 rpm, $10 \mathrm{~min}$, $4^{\circ} \mathrm{C}$ ) and the supernatant (crude enzyme) collected for analysis. Amylase activity was assayed by mixing $0.5 \mathrm{~mL}$ of crude enzyme with $0.5 \mathrm{~mL}$ of starch solution $(1 \%$ starch in $0.1 \mathrm{M}$ phosphate buffer, $\mathrm{pH}$ 6.5), and incubated for $30 \mathrm{~min}$ at $25 \pm 2^{\circ} \mathrm{C}$ (Hegde et al. 2011). The reducing sugar produced was determined using dinitrosalicylic acid (DNS) (Miller 1959) where $3 \mathrm{~mL}$ of DNS reagent was added to the reaction mixture, boiled at $90^{\circ} \mathrm{C}$ for $10 \mathrm{~min}$, followed by addition of $1 \mathrm{~mL}$ 
of $40 \%$ potassium sodium tartrate. After cooling, the absorbance was read at $540 \mathrm{~nm}$. The amount of glucose released was calculated from the glucose standard curve $\left(0-35 \mu\right.$ mole $\left.\mathrm{L}^{-1}\right)$. One unit (U) of amylase activity was defined as the amount of enzyme needed to release $1 \mu$ mole of glucose per min under assay conditions described.

The cellulase activities were assayed based on methods by Gautam et al. (2011). It was conducted similarly to amylase assay, where cultures were first established in culture broth (3 $\mathrm{g}$ $\mathrm{NaNO}_{3}, 0.1 \mathrm{~g} \mathrm{KH} \mathrm{KHO}_{4}, 0.5 \mathrm{~g} \mathrm{MgSO}_{4} .7 \mathrm{H}_{2} \mathrm{O}, 0.5 \mathrm{~g} \mathrm{KCl}, 1 \% \mathrm{CMC}$ ) leading to collection of supernatant. The supernatant $(0.5 \mathrm{~mL})$ was then mixed with $1.5 \mathrm{~mL}$ reaction mixture $(0.5 \mathrm{~mL}$ of $1 \%$ $\mathrm{CMC}, 1 \mathrm{~mL}$ of $0.1 \mathrm{M}$ sodium citrate buffer at $\mathrm{pH} 4.8$ ) and incubated for $60 \mathrm{~min}$ at $50 \pm 2^{\circ} \mathrm{C}$. The reducing sugar produced was determined using the DNS method as described in the previous section. One unit (U) of cellulase activity was defined as the amount of enzyme needed to release 1 $\mu$ mole of glucose per min under assay conditions described.

For chitinase activity, cultures were first established in $25 \mathrm{~mL}$ culture broth $\left(1 \mathrm{~g} \mathrm{KH}_{2} \mathrm{PO}_{4}\right.$, $0.5 \mathrm{~g} \mathrm{MgSO}_{4} .7 \mathrm{H}_{2} \mathrm{O}, 0.5 \mathrm{~g} \mathrm{KCl}, 5 \mathrm{~g}$ of $\mathrm{NaNO}_{3}, 0.5 \%$ crude chitin, $1 \mathrm{~L}$ sterile distilled water, $\mathrm{pH}$ 5) (Sharaf et al. 2012) and incubated at $25 \pm 2^{\circ} \mathrm{C}$ for 7 days. The culture was then centrifuged (5000 $\left.\mathrm{rpm}, 10 \mathrm{~min}, 4^{\circ} \mathrm{C}\right)$, the supernatant collected and transferred $(0.5 \mathrm{~mL})$ into a $1.5 \mathrm{~mL}$ reaction mixture (containing $1 \mathrm{~mL}$ of sterile distilled water, $0.5 \mathrm{~mL}$ of $0.2 \%$ colloidal chitin in $0.05 \mathrm{M}$ phosphate buffer at $\mathrm{pH}$ 5.2). The mixture was incubated for $30 \mathrm{~min}$ at $50 \pm 2^{\circ} \mathrm{C}$. The reducing sugar produced was determined using the DNS method as described in previous sections, with absorbance read at $575 \mathrm{~nm}$. The amount of $\mathrm{N}$-acetylglucosamine (NAGA) released was calculated from the NAGA standard curve constructed using concentrations of $0-30 \mu$ mole $\mathrm{L}^{-1}$. One unit (U) of chitinase activity was defined as the amount of enzyme needed to release $1 \mu$ mole of $\mathrm{N}$ acetylglucosamine per min under assay conditions as described.

\section{Antimicrobial properties of endophytes from Nepenthes spp.}

The antibacterial activities of endophytes were evaluated against five Gram Positive bacteria (Bacillus cereus, Streptococcus agalactiae, Streptococcus pyogenes, Staphylococcus aureus and Enterococcus faecalis) and five Gram Negative bacteria (Escherichia coli, Salmonella Typhi, Listeria monocytogenes, Pseudomonas aeruginosa and Klebsiella pneumonia). Plate assay based on methods by Kamalraj \& Muthumary (2012) were adopted. Briefly, mycelial plug (5 mm) of fungal endophytes were inoculated onto Nutrient Agar (NA) seeded with test organisms (48 h prior). Agar plugs were used as negative control. The cultures were refrigerated at $4 \pm 2{ }^{\circ} \mathrm{C}$ overnight to allow rapid diffusion of metabolites into the agar, and were subsequently incubated at $37 \pm 2^{\circ} \mathrm{C}$ for $24 \mathrm{~h}$. The diameter of inhibition zone was then measured.

The antifungal activity of endophytes were tested against three major plant pathogens in the tropics; Fusarium oxysporum f.sp. cubense tropical race 4, and Ganoderma boninense and $G$. miniatocinctum, pathogens of the Fusarium wilt and Ganoderma Basal Stem Rot disease, respectively. The assay was carried out according to Rahman et al. (2009). Briefly, mycelial plugs $(5 \mathrm{~mm})$ of the endophytes and the test pathogen (Fusarium oxysporum f.sp. cubense) were placed on the same petri dish (paired-cultures), at an equi-distance of $3 \mathrm{~cm}$ from each other and from the periphery of the plate. Agar plugs were used as control. These paired-cultures were incubated at $25 \pm 2^{\circ} \mathrm{C}$ for 6 days. The percentage of inhibition of radial growth (PIRG) was determined as:

$$
\operatorname{PIRG}(\%)=\mathrm{R} 1-\mathrm{R} 2 / \mathrm{R} 1 \times 100 \%
$$

where R1 represents the radial growth of pathogen in control; and R2 the radial growth of pathogen in paired-cultures. The procedure was repeated for all endophytes paired with various pathogens.

\section{Identification of selected endophytes from Nepenthes spp.}

Endophytes with strong enzymatic and antimicrobial activities were selected for identification based on DNA sequencing. Cultures were first established in Potato Dextrose Broth for 7 days, in which $300 \mathrm{mg}$ fresh weight of the mycelia was harvested and used for genomic DNA extraction. The extraction was performed using the GF-1 Plant DNA Extraction kit (Vivantis, Malaysia) that is also suitable for fungi. Maxime PCR PreMix Kit (iNtRON Biotechnology, Korea) 
was used for the PCR reaction mixture $(20 \mu \mathrm{L})$, which was added with $5 \mu \mathrm{L}$ DNA template, $1 \mu \mathrm{L}$ universal forward primer ITS1 (5'TCCGTAGGTGAACCTGCGG3'), $1 \mu \mathrm{L}$ universal reverse primer ITS4 (5'TCCTCCGCTTATTGATATGC3'), and $13 \mu \mathrm{L}$ sterile distilled water. PCR was performed with the following temperature program, initial denaturation at $94^{\circ} \mathrm{C}$ for $120 \mathrm{~s}$; denaturation at $94^{\circ} \mathrm{C}$ for $20 \mathrm{~s}$; annealing at $60^{\circ} \mathrm{C}$ for $10 \mathrm{~s}$; extension at $67^{\circ} \mathrm{C}$ for $45 \mathrm{~s}$; final extension at $72^{\circ} \mathrm{C}$ for $240 \mathrm{~s}$. Denaturation, annealing and extension were repeated for 35 cycles. The PCR products were then purified using MEGA quick-spin Total Fragment DNA Purification Kit (iNtRON Biotechnology, Korea) and outsourced to First Base (Malaysia) for DNA sequencing. Once the DNA sequencing results were obtained, they were edited using the BioEdit (v7.1.3) program. The sequences were subjected to BLAST to determine the most probable species based on similarity $(\%)$ with existing isolates in the database.

\section{Statistical analysis}

All assays were performed in triplicates. The data obtained was subjected to One-way Analysis of Variance (ANOVA) with means compared using the Tukey's Studentized Test $\left(\operatorname{HSD}_{(0.05)}\right)$. All statistical analyses were carried out using SPSS statistical software package v. 20 (IBM).

\section{Results}

\section{Isolation and identification of beneficial endophytes from Nepenthes spp.}

A higher number of beneficial endophytes were recovered from $N$. ampullaria (9 isolates), from both leaves and pitchers, compared to $N$. mirabilis (3 isolates). Of the 12 endophytes sequenced, we obtained 11 filamentous fungi and one yeast-like fungi (Table 1). Majority of the isolates were common endophytic species, such as Glomerella sp. (isolate 10) or their anamorph Colletotrichum gloeosporioides (isolates 20, 23), Phomopsis sp. (isolates 5, 15), Trichoderma asperellum (isolate 3), Aspergillus terreus (isolate 24) and Penicillium simplicissimum (isolate 19) (Table 1). Several uncommon species such as Lasiodiplodia, Isaria, Sarcosomataceous and a yeastlike fungi Meyerozyma guilliermondii were also identified as probable species for isolates 13, 22, 25 and 9, respectively (Table 1). For isolate 20 and 23, we designated these isolates as Colletotrichum gleosporiodes species complex thereafter in this article as identification through ITS sequences alone is not sufficient to distinguish them and will require additional gene sequences (Weir et al. 2012).

Table 1 Most probable species of culturable endophytes from N. ampullaria and N. mirabilis.

\begin{tabular}{cccccl}
\hline Isolates & $\begin{array}{c}\text { Location } \\
\text { in plant }\end{array}$ & $\begin{array}{c}\text { Query } \\
\text { cover } \\
\text { percentage } \\
(\boldsymbol{\%})\end{array}$ & $\begin{array}{c}\text { Identity } \\
\text { percentage } \\
(\boldsymbol{\%})\end{array}$ & $\begin{array}{c}\text { E- } \\
\text { value }\end{array}$ & Most probable identity \\
\hline 3 & AL & 99 & 99 & 0 & Trichoderma asperellum \\
5 & AL & 98 & 99 & 0 & Phomopsis sp. \\
9 & AL & 100 & 99 & 0 & Meyerozyma guilliermondii \\
10 & AP & 100 & 100 & 0 & Glomerella sp. \\
13 & AP & 100 & 99 & 0 & Lasiodiplodia sp. \\
15 & ML & 99 & 97 & 0 & Phomopsis sp. \\
19 & MP & 100 & 100 & 0 & Penicillium simplicissimum \\
20 & MP & 100 & 100 & 0 & Colletotrichum \\
22 & AL & 98 & 99 & 0 & Isloeosporiodes \\
23 & AL & 99 & 100 & 0 & Colletotrichum gloeosporiodes \\
24 & AP & 100 & 99 & 0 & Aspergillus terreus \\
25 & AP & 98 & 96 & 0 & Sarcosomataceous sp. \\
\hline
\end{tabular}

* AL, N. ampullaria leaf; AP, N. ampullaria pitcher; ML, N. mirabilis leaf; MP, N. mirabilis pitcher 


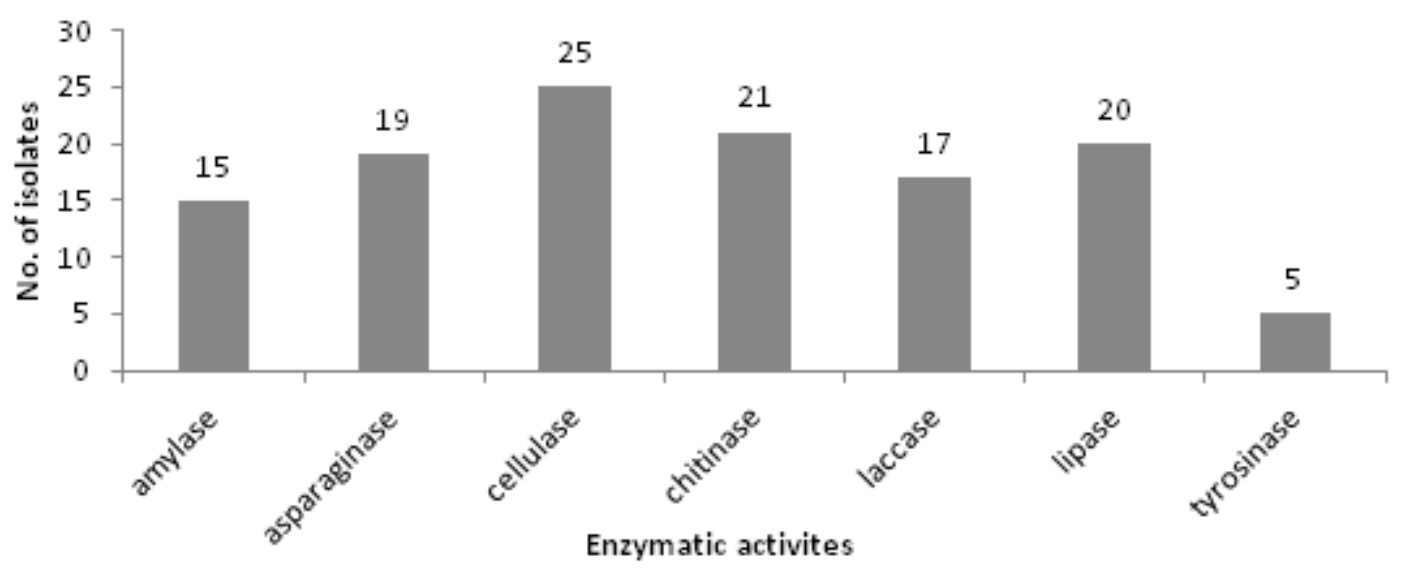

Fig. 1 - Total number of fungal endophytes expressing various enzymatic activities.

\section{Enzymes produced by endophytes from Nepenthes spp.}

The most common enzyme produced by the endophytes from Nepenthes spp. is cellulase, followed by chitinase, lipase, asparaginase, laccase, amylase and finally, tyrosinase, with 25, 21, 20, 19, 17, 15 and 5 positive isolates, respectively (Fig. 1). A comparison among endophytes revealed that isolates 9 (M. guilliermondii), 10 (Glomerella sp.) and 13 (Lasiodiplodia sp.) produced all enzymes assayed. The ratio of halo zone diameter to colony diameter for isolates 9,10 and 13 were between 0.122 to $3.122,0.242$ to 1.438 , and 0.64 to 1.315 , respectively and were not necessarily the highest for each enzyme. Among the isolates, isolate 9 (M. guilliermondii) showed particularly strong lipase (ratio of 3.122) and asparaginase (ratio of 2.353) production. Phomopsis sp. (isolate 5) produced strong laccase activity (1.087) while strong amylase production was detected in P. simpliscissimum (isolate 19), A. terreus (isolate 24) and Lasiodiplodia sp. (isolate 13), each with a ratio of 1.0. Tyrosinase activity was only detected in four isolates; Glomerella $\mathrm{sp}$. (isolate 10), Lasidiplodia sp. (isolate 13), Sarcosomataceous sp. (isolate 25) and M. guilliermondii (isolate 9), with ratios of $0.096,1.0,1.0$ and 0.122 , respectively.

\section{Activities of key enzymes produced by selected endophytes}

When comparing the two isolates (9 and 10) for amylase, cellulase, chitinase and laccase activities, isolate 10 (Glomerella sp.) showed better potential than isolate 9 (M. guilliermondii), with significantly higher cellulase, laccase and chitinase activities at $0.0276 \mathrm{U} \mathrm{mL}^{-1}, 0.0600 \mathrm{U} \mathrm{mL}^{-}$ ${ }^{1}$, and $0.0019 \mathrm{U} \mathrm{mL}^{-1}$, respectively. Isolate 9 however, recorded significantly higher amylase activity of $2.1133 \mathrm{~mL}^{-1}$ compared to $0.01291 \mathrm{U} \mathrm{mL}^{-1}$ produced by isolate 10 (Figure 2). Isolate 13 was not tested as ratios derived from this isolate were relatively low compared to isolate 9 and 10, although all three isolates produced all seven enzymes assayed.

\section{Antimicrobial properties of endophytes from Nepenthes sp.}

Of the 26 isolates tested for antimicrobial properties, only one endophyte (isolate 17) showed antibacterial activity while 4, 7 and 10 isolates produced antifungal activities ( $>50 \%$ PIRG) towards G. miniatocinctum, G. boninense and Foc race 4, respectively (Figure 3). Isolate 17 inhibited the growth of Streptococcus pyogenes and Enterococcus faecalis with inhibitory diameter (mean $\pm \mathrm{SD}$ ) of $25 \pm 0.58 \mathrm{~mm}$ and $29 \pm 1.7 \mathrm{~mm}$, respectively (data not shown). However, this isolate did not produce strong antifungal activity (Fig. 3). Endophytes with antifungal activities towards pathogens were either via competitive exclusion (Fig. 4A), secretion of inhibitory metabolites resulting in a clear inhibition zone (Figure 4B), or a combination of both. Isolate 3 (T. asperellum) was consistently effective towards all three pathogens with significantly higher PIRG values of $77.55 \%$ to $97.14 \%$ (Fig. 3). The other isolates with antifungal activities towards all three pathogens were isolates 23 (C. gloeosporiodes species complex), 13 (Lasiodiplodia sp.) and 19 ( $P$. simplicissimum), with PIRG values ranging from $68.75 \%$ to $72.45 \%, 49.44 \%$ to $67.35 \%$ and $60.00 \%$ to $67.35 \%$ respectively (Fig. 3). Mechanisms of inhibition were found to be similar for all of these three isolates, via competitive exclusion mechanism. Other isolates that were found to 


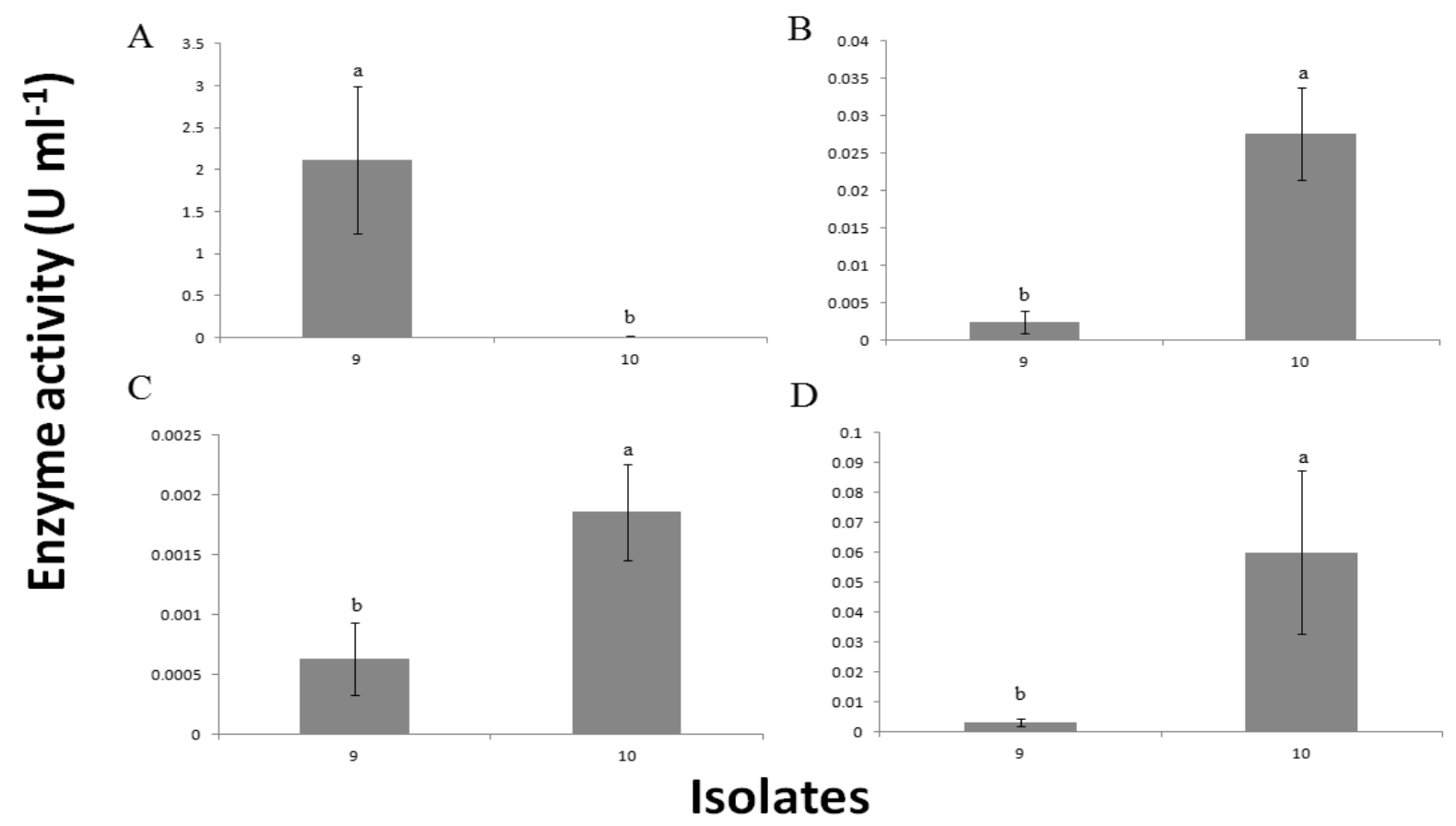

Fig. 2 - Enzymatic assay of A, amylase. B, cellulose. C, chitinase. D, laccase of selected isolates. Values are means of triplicates. Means with the same letters are not significantly different $\operatorname{HSD}_{(0.05)}$. Bars are standard deviations of means.

inhibit G. boninense were isolates 22 (Isaria sp.) and 24 (A. terreus) while isolates 15 (Phomopsis sp.), 24 (A. terreus) and 25 (Sarcosomataceous sp.) have antifungal activities towards $G$. miniatocinctum as well (Figure 3). These isolates exhibit pathogens via competitive exclusion mechanism. Only three isolates, isolate 5 (Phomopsis sp.), 20 (C. gloeosporiodes species complex) and 25 (Sarcosomataceous sp.) displayed inhibition of fungal pathogen via secretion of secondary metabolites (Fig. 3).

\section{Discussion}

This report is the first to document the discovery of six different species (Glomerella sp., Lasiodiplodia sp., P. simplicissimum, C. gloeosporioides species complex, A. terreus and Sarcosomataceous) of fungal endophytes from the pitchers of $N$. ampullaria and N. mirabilis. Although fungal endophyte species have been found in other carnivorous plants such as the "trumpet pitchers" Sarracenia (Glen \& Bodri 2012), "sundews" Drosera (Quilliam \& Jones 2010) and "butterworts" Pinguicula (Quilliam \& Jones 2012), this is the first report for tropical $N$. ampullaria and N. mirabilis. Of the many species, we find only $C$. gloeosporioides species complex that was recovered from both $N$. ampullaria and $N$. mirabilis. This species was also recovered from both pitchers and leaves (Table 1). Our finding here agrees with Glen \& Bodri (2012) who also found $C$. gloeosporioides species complex as a true endophyte of Sarracenia due to their presence in different individuals, locations and years in this plant. We thereby postulate that C. gloeosporioides species complex could also be a possible true endophyte of $N$. ampullaria and $N$. mirabilis. These endophytic species, although is the first reporting for $N$. ampullaria and $N$. mirabilis, were common endophytes of rubber trees (Gazis \& Chaverri 2010), banana plants (Xia et al. 2011), and medicinal plants such as Eucalyptus nitens (Fisher et al. 1993), Justicia gendarussa (Gangadevi \& Muthumary 2008) and Forsythia suspense (Zhang et al. 2012). These species have limited documentation of their endophytic nature, having only reports of M. guilliermondii from leaves of nickel-hyperaccumulator plant Berkheya coddii (Postma et al. 2012), Sarcosomataceous sp. from the pearlwort Colobanthus quitensis (Rosa et al. 2010), and Lasiodiplodia sp. from the pepper plant Piper hispidum (Orlandelli et al. 2012), Eucalyptus and Acacia (Burgess et al. 2006, Zhao et al. 2010). 


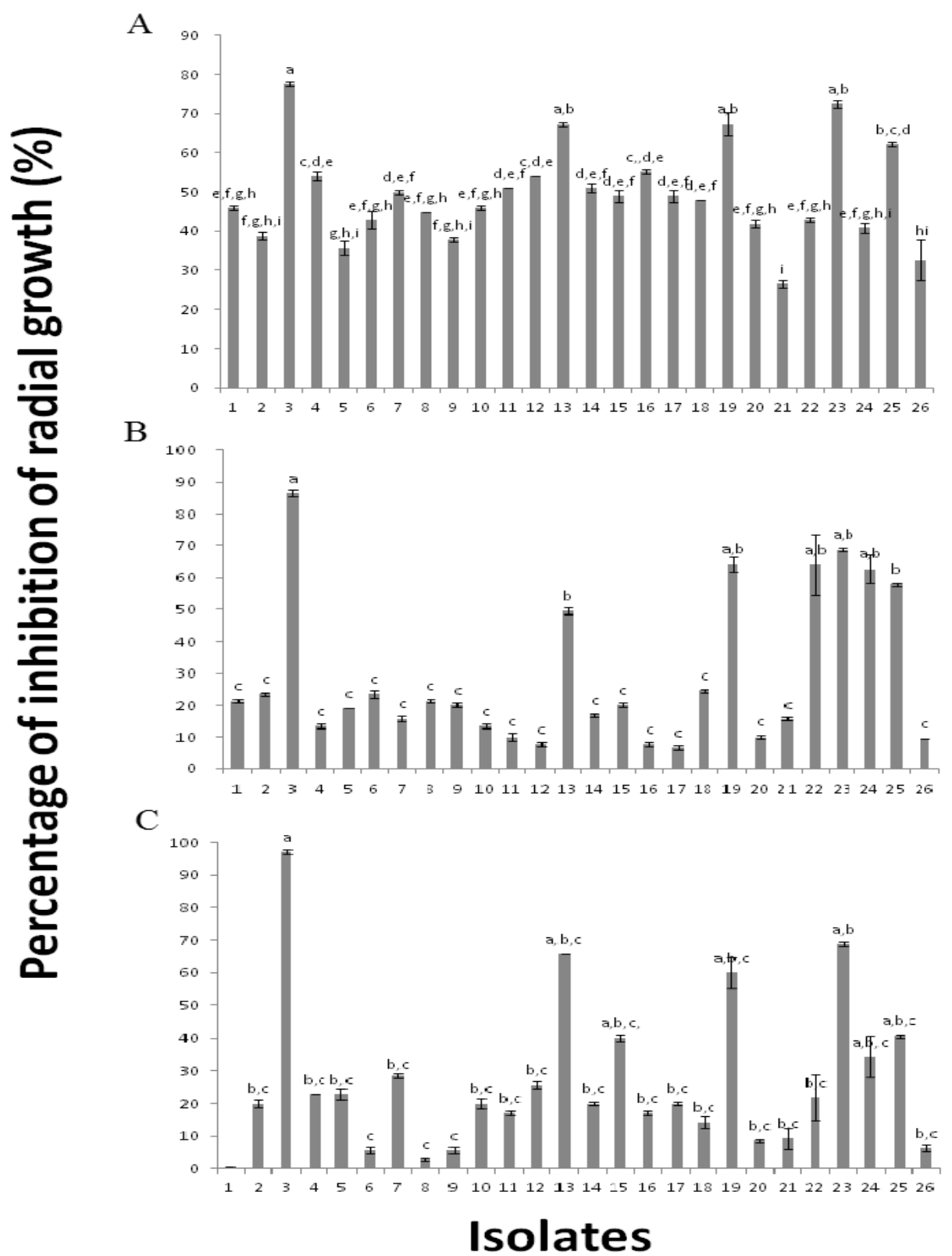

Fig. 3 - Percentage of inhibition of radial growth (PIRG \%) of fungal endophytes against A, Fusarium oxysporum f. sp. Cubense. B, Ganoderma boninense, C, Ganoderma miniatocinctum, Values are means of triplicates. Means with the same letters are not significantly different $\operatorname{HSD}_{(0.05)}$. Bars are standard deviations of means.

We note with interest that most of these endophytes have cellulase, chitinase and lipase activities; enzymes that are involved in the digestion of preys such as arthropods and leaf litters in pitchers (Mohan \& Clarke 2010, Suderman et al. 2010, Pavlovic et al. 2011, Pavlovic, 2012). Although we cannot conclude the role of endophytes in prey digestion based on our results here, they support hypotheses by Morohoshi et al. (2011) and Takeuchi et al. (2011), linking enzyme production to the microbial community in the pitcher fluid rather than from the plant. Endogenous production of these enzymes by pitcher-plants is not known hence microbes, possibly including endophytes, have a vital role in prey digestion. Our results also strongly suggest that the prevalence of these enzymes may be aligned to the primary enzymes required by pitcher plants for physiological needs, possibly in response to co-evolution and host-selection pressure. Hence, pitcher plants which rely heavily on cellulases, chitinases and lipases for prey and leaf litter digestion, may drive the dominant expression of these enzymes in the endophytes. 

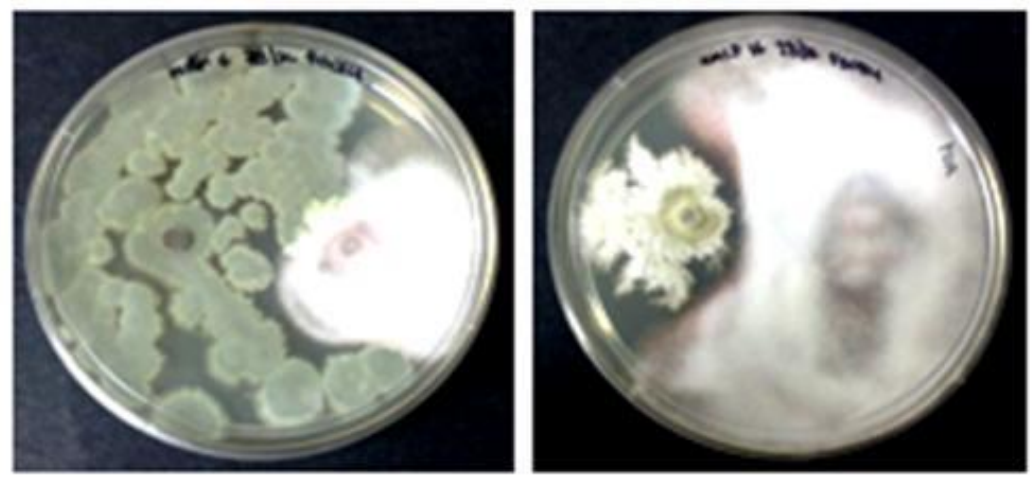

Fig. 4 - Mechanisms of antifungal activity by fungal endophytes (left) against fungal pathogen (right) either through (A) overgrowth or (B) secretion of secondary metabolites.

The other enzymes (amylases, laccases, asparaginases and tyrosinases) are not well-understood as either produced by Nepenthes spp. or their endophytes (Tokes et al. 1974). Our study here is the first to report on lipase and tyrosinase activity by endophytic M. guilliermondii. Other endophytes produced typical enzymes that has been reported elsewhere; Phomopsis for laccase production (Vedashree et al. 2013), P. simplicissimum and A. terreusfor amylase (Zeng et al. 2006, Kuntal and Kumar 2012, Alhussaini 2013). Similarly, there are reports of Lasiodiplodia producing amylase (Salami and Akintokun 2008, Adejuwon 2011) but their production of tyrosinase has so far not been documented. A quick comparison with literatures revealed that amylase activities by endophytes from Nepenthes (isolate 9 and 10) were comparable to levels by endophytic Pestalotiopsis microspora strain VB5 and Aspergillus oryzae strain VB6 from mangroves (Joel \& Bhimba, 2012). However, isolates 9 and 10 have inferior levels of laccase, cellulase, chitinase production compared to endophytic Monotospora sp. in Cynodon dactylon (Wang et al. 2006), Phomopsis sp. in Bischofia polycarpa (Dai et al. 2010), P. glabrum in Espeletia spp. (Cabezas et al. 2012), and endophytes from Phragmites australis, Choiromyces aboriginum, Stachybotrys elegans and Cylindrocarpon sp. (Cao et al. 2009).

Antimicrobial properties of the endophytes were attributed to the competitive exclusion mechanism whereby isolates were able to out-compete fungal pathogens for resources such as growing space and nutrient. It could also be attributed to the cell-wall degrading enzymes such as chitinase and $\beta$-1,3-gluconidase (Qualhato et al. 2013). The antimicrobial potential of endophytes from Nepenthes spp. is similar to endophytes from other various host species. Phomopsis sp. and $C$. gloeosporiodes species complex are known to produce bioactive inhibitory compounds such as alkaloids, terpenoids, phenolics (Silva et al. 2006, Huang et al. 2008, Fu et al. 2011, Brum et al. 2012).

To conclude, this study identified culturable endophytes from tropical pitcher plants, and highlighted their enzymatic and antifungal potential. Most of the beneficial endophytes belonged to the common genus of Colletotrichum, while atypical species such as Lasiodiplodia, Isaria and Meyerozyma guilliermondii were also identified. These species are interesting source of important enzymes and antifungal compounds. Our results here contribute to the understanding of endophytes from pitcher plants and their functional use.

\section{Acknowledgements}

This work was financed by Monash University Malaysia.

\section{References}

Adejuwon AO. 2011 - Nutritional factors affecting the production of $\alpha$-amylase in Lasiodiplodia theobromae Pat.. Biotechnology, Bioinformatics and Bioengineering 1, 131-135. 
Ahmed I, Hussain H, Schulz B, Draeger S, Padula D, Pescitelli G, van Ree, Krohn K. 2011 - Three new antimicrobial metabolites from the endophytic fungus Phomopsis sp.. European Journal of Organic Chemistry 15, 808-812.

Alhussaini MS 2013 - Mycobiota of wheat flour and detection of $\alpha$ - Amylase and L-asparaginase enzymes. Life Science Journal 10, 1112-1122.

Appel IM, van Kessel-Bakvis C, Stigter R, Pieters R. 2007 - Influence of two different regimens of concomitant treatment with asparaginase and dexamethason on hemostasis in childhood acute lymphoblastic leukemia. Leukemia 21, 2377-80.

Arnold AE, Lutzoni F. 2007 - Diversity and host range of foliar fungal endophytes, are tropical leaves biodiversity hotspots? Ecology 8, 541-549.

Athauda SPB, Matsumoto K, Rajapakshe S, Kuribayashi M, Kojima M, Kubomura-Yoshida N, Iwamatsu A, Shiba C, Inoue H, Takahashi K. 2004 - Erratum, Enzymatic and structural characterization of nepenthesin, a unique member of a novel subfamily of aspartic proteinase. Biochemical Journal 381, 295-306.

Bhagobaty RK, Joshi, SR. 2012 - Enzymatic activity of fungi endophytic on five medicinal plant species of the pristine sacred forest of Meghalaya, India. Biotechnology and Bioprocess Engineering 17, 33-40.

Brum MC, Araujo WL, Maki CS, Azevedo JL. 2012 - Endophytic fungi from Vitis labrusca L. ('Niagara Rosada') and its potential for the biological control of Fusarium oxysporum. Genetics and molecular research, GMR 11, 4187-4197.

Burgess TI, Barber PA, Mohali S, Pegg G, De Beer W, Wingfield MJ. 2006 - Three new Lasiodiplodia spp. from the tropics, recognized based on DNA sequence comparisons and morphology. Mycologia 98, 423-435.

Cabezas L, Calderon C, Medina LM, Bahamon L, Cardenas M, Bernal AJ, Gonzalez A, Restrepo S. 2012 - Characterization of cellulases of fungal endophytes isolated from Espeletia spp. Journal of Microbiology 50, 1009-1013.

Cao R, Liu X, Gao K, Mendgen K, Kang Z, Gao J, Dai Y, Wang X. 2009 - Mycoparasitism of endophytic fungi isolated from reed on soilborne phytopathogenic fungi and production of cell wall-degrading enzymes in vitro. Current Microbiology 59, 584-592.

Chujo T, Scott B. 2014 - Histone H3K9 and H3K27 methylation regulates fungal alkaloid biosynthesis in fungal endophyte-plant symbiosis. Molecular Microbiology, DOI: 10.1111/mmi.12567.

Dai CC, Chem Y, Tian LS, Shi Y. 2010 - Correlation between invasion by endophytic fungus Phomopsis sp. and enzyme production. African Journal of Agricultural Research 5, 1324-1330.

Debbab A, Aly AH, Proksch P. 2012 - Endophytes and associated marine derived fungi ecological and chemical perspectives. Fungal Diversity, DOI: 10.1007/s13225-012-0191-8.

Deng Z, Cao L, Huang H, Jiang X, Wang W, Shi Y, Zhang R. 2011 - Characterization of Cd- and $\mathrm{Pb}$ - resistant fungal endophyte Mucor sp. CBRF59 isolated from rapes (Brassica chinensis) in a metal-contaminated soil. Journal of Hazardous Materials 2-3, 717-724.

Eilenberg H, Pnini-Cohen S, Schuster S, Movtchan A, Zilberstein A. 2006 - Isolation and characterization of chitinase genes from pitchers of the carnivorous plant Nepenthes khasiana. Journal of Experimental Botany 57, 2775-2784.

Fang W, Leng B, Xiao Y, Jin K, Ma J, Fan Y, Feng J, Yang X, Zhang Y, Pei Y. 2005 - Cloning of Beauveria bassiana chitinase gene Bbchit1 and its application to improve fungal strain virulence. Applied and Environmental Microbiology 71, 363-370.

Fisher PJ, Petrini O, Sutton, BC. 1993 - A comparative study of fungal endophytes in leaves, xylem and bark of Eucalyptus in Australia and England. Sydowia 45, 338-345.

Fu J, Zhou Y, Li H-F, Ye Y-H, Guo J-H. 2011 - Antifungal metabolites from Phomopsis sp. By254, an endophytic fungus in Gossypium hirsutum. African Journal of Microbiology Research 5,1231-1236.

Fungi. Human Daxue Xuebao/ Journal of Human University Natural Sciences 35, 71-74. 
Gangadevi V, Muthumary J. 2008 - Isolation of Colletotrichum gloeosporioides, a novel endophytic taxol-producing fungus from the leaves of a medicinal plant, Justicia gendarussa. Mycologia Balcanica 5, 1-4.

Gautam SP, Bundela PS, Pandey AK, Jamaluddin K, Awasthi MK, Sarsaiya S. 2011 Optimization for the production of cellulose enzyme from municipal solid waste residue by two novel cellulolytic fungi. Biotechnology Research International. doi, 10.4061/2011/810425.

Gazis R, Chaverri P. 2010 - Diversity of fungal endophytes in leaves and stems of wild rubber trees (Hevea brasiliensis) in Peru. Fungal Ecology 3, 240-254.

Glen A, Bodri MS. 2012 - Fungal endophyte diversity in Sarracenia. PLoS ONE 7, art no. e32980.Gunatilaka AAL 2006 - Natural products from plant-associated microorganisms, Distribution, structural diversity, bioactivity, and implications of their occurrence. Journal of Natural Products 69, 509-526.

Hamayun M, Khan SA, Khan AL, Rehman G, Kim Y-H, Iqbal L, Hussain J, Lee I-J, Sohn E-Y. 2010 - Gibberellin production and plant growth promotion from pure cultures of Cladosporium sp. MH-6 isolated from cucumber (Cucumis sativus L.). Mycologia 102, 989-995.

Hazalin NAMN, Ramasamy K, Lim SM, Wahab IA, Cole ALJ, Majeed ABA. 2009 - Cytotoxic and antibacterial activities of endophytic fungi isolated from plants at the National Park, Pahang, Malaysia. BMC Complementary and Alternative Medicine, doi: 10.1186/14726882-9-46.

Hegde SV, Ramesha A, Srinvas C. 2011 - Optimization of amylase production from endophytic fungi Discosia sp. isolated from Calophyllum inophyllum. Journal of Agricultural Technology 7, 805-813.

Hoffman MT, Gunatilaka MK, Wijeratne K, Gunatilaka L, Arnold AE. 2013 - Endohyphal Bacterium enhances production of indole-3-acetic acid by a foliar fungal endophyte. PLoS ONE 8(9): e73132, doi:10.1371/journal.pone.0073132

Huang WY, Cai YZ, Hyde KD, Corke H, Sun M. 2008 - Biodiversity of endophytic fungi associated with 29 traditional Chinese medicinal plants. Fungal Diversity 33, 61-75.

Islam S, Akanda AM, Prova A, Sultana F, Hossain MM. 2014 - Growth promotion effect of Fusarium spp. PFF1 from bermudagrass (Cynodon dactylon) rhizosphere on Indian spinach (Basella alba) seedlings are linked to root colonization. Archives of Phytopathology and Plant Protection, DOI: 10.1080/03235408.2013.876745

Joel El, Bhimba BV. 2012 - Production of alpha amylase by mangrove associated fungi Pestalotiopsis microspora strain VB5 and Aspergillus oryzae strain VB6. Indian Journal of Geo-Marine Sciences 41, 279-283.

Kamalraj S, Muthumary J. 2012 - Screening and identification of potential Coelomycetous strains for the production of extracellular antimicrobial metabolites. Asian Journal of Pharmaceutical and Clinical Research 5, 137-145.

Khan AL, Waqas M, Hussain J, Al-Harrasi A, Lee IJ. 2014 - Fungal endophyte Penicillium janthinellum LK5 can reduce cadmium toxicity in Solanum lycopersicum (Sitiens and Rhe). Biology and Fertility of Soils 50(1), 75-85.

Kuntal A, Kumar N. 2012 - Impact of metal ions on the degradation of agrowaste by Aspergillus terreus. Journal of Pure and Applied Microbiology 6, 1327-1332.

Kusari P, Kusari S, Spiteller M, Kayser O. 2012. Endophytic fungi harboured in Cannabis sativa 1.: diversity and potential as biocontrol agents against host plant-specific phytopathogens. Fungal Diversity, DOI: 10.1007/s13225-012-0216-3

Kusari S. Lamshoft M, Zühlke S, Spiteller M, 2008 - An endophytic fungus from Hypericum perforatum that produces hypericin. Journal of Natural Products 71, 159-162.

Li E, Jiang L, Guo L, Zhang H, Che Y. 2008 - Pestalachlorides A-C, antifungal metabolites from the plant endophytic fungus Pestalotiopsis adusta. Bioorganic and Medicinal Chemistry Letters 16, 7894-7899 
Li H-Y, Zhao C-A, Liu C-J, Xu, X-F. 2010 - Endophytic fungi diversity of aquatic/riparian plants and their antifungal activity in vitro. Journal of Microbiology 1, 1-6.

Liu Y-G, Feng B-Y, Fan T, Pan C, Peng L-J. 2008 - Study on the biosorption of heavy metals by

Mandyam K, Loughin T, Jumpponen A. 2010 - Isolation and morphological and metabolic characterization of common endophytes in annually burned tallgrass prairie. Mycologia $102,813-821$.

Maria GL, Sridhar KR, Raviraja NS. 2005 - Antimicrobial and enzyme activity of mangrove endophytic fungi of southwest coast of India. Journal of Agricultural Technology 1, 67-80.

Microbial Ecology 2, 404-416.

Miller GL. 1959 - Use of dinitrosalicyclic acid reagent for determination of reducing sugar. Analytical Chemistry 31, 426-428.

Mohan JA, Clarke CM. 2010 - The carnivorous syndrome in Nepenthes pitcher plants. Plant Signaling \& Behavior 5, 644-648.

Mohana KP, Sebastian V, Vaidyanathan P, Thimmappa RB, Singh S, Gudasalamani R, Ramesh V, Retnabai ST, Michael S, Uma SR. 2012 - Fusarium proliferatum an endophytic fungus from Dyxolum binetariferum Hook.f produces rohitukine, a chromane alkaloid possessing anti-cancer activity. Antonie van Leeuwenhoek 101, 323-329.

Morohoshi T, Oikawa M, Sato S, Kikuchi N, Kato N, Ikeda T. 2011 - Isolation and characterization of novel lipases from a metagenomic library of the microbial community in the pitcher fluid of the carnivorous plant Nepenthes hybrida. Journal of Bioscience and Bioengineering 112, 315-350.

Okay S, Tefon BE, Ozkan M, Ozcengiz G. 2008 - Expression of chitinase A (chiA) gene from a local isolate of Serratia marcescens in Coleoptera-specific Bacillus thuringiensis. Journal of Applied Microbiology 104, 161-170.

Orlandelli RC, Alberto RN, Rubin Filho CJ, Pamphile JA. 2012 - Diversity of endophytic fungal community associated with Piper hispidum (Piperaceae) leaves. Genetics and Molecular Research 11, 1575-1585.

Pandey A, Nigam P, Soccol CR, Soccol VT, Singh D, Mohan R. 2000 - Advances in microbial amylases. Biotechnology Application Biochemistry 31, 135-152.

Pavlovic A 2012 - Adaptive radiation with regard to nutrient sequestration strategies in the carnivorous plants of the genus Nepenthes. Plant Signalling and Behavior 7, 295-297.

Pavlovic A, Slovakova L, Santrucek J. 2011 - Nutritional benefit from leaf litter utilization in the pitcher plant Nepenthes ampullaria. Plant, Cell and Environment 34, 1865-1873.

Postma F, Mesjasz-Przybylowicz J, Przybylowicz W, Stone W, Mouton M, Botha A. 2012 Symbiotic interactions of culturable microbes with the nickel hyperaccumulator Berkheya coddii and the herbivorous insect Chrysolina clathrata. Symbiosis 58, 209-220.

Praptiwi, Jamal Y, Fathoni A, Nurkanto A, and Agusta A. 2013 - 3-Acetyl-2,5,7-Trihydroxyl-1,4naphtalenedione

Qualhato TF, Lopes FAC, Steindorff AS, Brandao RS, Jesuino RSA, Ulhoa CJ. 2013. Mycoparasitism studies of Trichoderma species against three phytopathogenic fungi, Evaluation of antagonism and hydrolytic enzyme production. Biotechnology Letters 35, 1461-1468.

Quilliam RS, Jones DL. 2010 - Fungal root endophytes of the carnivorous plant Drosera rotundifolia. Mycorrhiza 20, 341-348.

Quilliam RS. Jones DL. 2012 - Evidance for host-specificity of culturable fungal root endophytes from the carnivorous plant Pinguicula vulgaris (Common Butterwort). Mycological Progress 11, 583-585.

Rahman MA, Begum MF, Alam MF. 2009 - Screening of Trichorderma isolates as a biological control agent against Ceratocystic paradoxa causing pineapple disease of sugarcane. Microbiology 37, 277-285.

Raju BGS, Rao GH, Ayyanna C. 1993 - Bioconversion of L-tyrosine to L-DOPA using Aspergillus oryzae. CBS Publishers, Visakhapatnam, India, pp. 106-110. 
Rodriguez RJ, Henson J, Van Volkenburgh E, Hoy M, Wright L, Beckwith F, Kim Y, Redman RS. 2008 - Stress tolerance in plants via habitat-adapted symbiosis. International Society for

Rosa LH, Almeida Vieira MDL, Santiago IF, Rosa CA - 2010. Endophytic fungi community associated with the dicotyledonous plant Colobanthus quitensis (Kunth) Bartl. (Caryophyllaceae) in Antarctica. FEMS Microbiology Ecology 73, 178-189.

Salami AO, Akintokun AK. 2008 - Post-harvest enzymatic activities of healthy and infected cassava (Manihot esculenta Crantz) tubers. Emirates Journal of Food and Agriculture 20, 117.

Sandhu SS, Sharma AK, Beniwal V, Boel G, Batra P, Kumar A, Jaglan S, Sharma AK, Malhotra S. 2012 - Myco-biocontrol of insect pests, factor involved, mechanism, and regulation. Journal of Pathogen. 2012,126819.

Schulz BJE, Boyle CJC, Sieber TN. 2006 - Microbial root endophytes. Springer Berlin Heidelberg, Germany.

Sharaf EF, El-Sarrany AEQ, El-Deeb M. 2012 - Biorecycling of shrimp shell by Trichoderma viride for production of antifungal chitinase. African Journal of Microbiology Research 21, 4538-4545.

Silva GH, Teles HL, Zanardi LM, Marx YMC, Eberlin MN, Hadad R, Pfenning LH, Costa-Neto CM, Castro-Gamboa 1, Bolzani YS, Araujo AR. 2006 - Cadinane sesquiterpenoids of Phomopsis cassia, an endophytic fungus associated with Cassia spectabilis (Leguminosae). Phytochemistry 67, 1964-1969.

Silva HAS, Tozzi JPL, Terrasan CRF, Bettiol W. 2012 - Endophytic microorganisms from coffee tissues as plant growth promoters and biocontrol agents of coffee leaf rust. Biological Control 63(1), 62-67.

Singh LP, Gill SS, Tetuje N. 2011 - Unravelling the role of fungal symbionts in plant abiotic stress tolerance. Plant Signalling \& Behavior 6, 175-191.

St Leger RJ, Wang C. 2010 - Genetic engineering of fungal biocontrol agents to achieve greater efficacy against insect pests. Applied Microbiology and Biotechnology 85, 901-907.

Stephenson P, Hogan J. 2006 - Cloning and characterization of a ribonuclease, a cysteine proteinase, and an aspartic proteinase from pitchers of the carnivorous plant Nepenthes ventricosa blanco. International Journal of Plant Sciences 167, 239-248.

Suderman RJ, Dittmer NT, Kramer KJ, Kanost MR. 2010 - Model reactions for insect cuticle sclerotization, participation of amino groups in the cross-linking of Manduca sexta cuticle protein MsCP36. Insect Biochemistry and Molecular Biology 40, 252-258.

Takeuchi Y, Salcher MM, Ushio M, Shimizu-Inatsugi R, Kobayashi MJ, Diway B, von Mering C, Pernthaler J, Shimizu KK. 2011 - In situ enzyme activity in the dissolved and particulate fraction of the fluid from four pitcher plant species of the genus Nepenthes. PLoS ONE 6, e25144.

Theantana H, Hyde KD, Lumyong S. 2007 - Asparaginase production by endophytic fungi isolated from some Thai medicinal plants. KMITL Science and Technology Journal 7, 13-18.

Thirunavukkarasu N, Suryanarayanan TS, Murali TS, Ravishankar JP, Gummadi SN. 2011 - Lasparaginase from marine derived fungal endophytes of seaweeds. Mycophere 2, 147-155.

Tintjer T, Rudgers JA. 2006 - Grass-herbivore interactions altered by strains of a native endophyte. New Phytologist 170, 513-521.

Tokes ZA, Woon WC, Chambers SM. 1974 - Digestive enzymes secreted by the carnivorous plant Nepenthes macferlanei L.. Planta 1 19, 39-46.

U'Ren, Lutzoni F, Miadlikowska J, Laetsch AD, Elizabeth Arnold A. 2012 - Host and geographic structure of endophytic and endolichenic fungi at a continental scale. American Journal of Botany 99, 898-914.

Vedashree S, Sateesh MK, Lakshmeesha TR, Mohammed SS, Vedamurthy AK. 2013 - Screening and assay of extracellular enzymes in Phomopsis azadirachtae causing die-back disease of neem. Journal of Agricultural Technology 9, 915-927. 
Vega FE, Posada F, Aime MC, Pava-Ripoll M, Infante F, Rehner SA. 2008 - Entomopathogenic fungal endophytes. Biological Control 46, 72-82.

Wang JW, Wu JH, Huang WY, Tan RX. 2006 - Laccase production by Monotospora sp., an endophytic fungus in Cynodon dactylon. Bioresource Technology 97, 786-789.

Weir BS, Johnston PR, Damm U. 2012 - The Colletotrichum gloeosporiodes species complex. Studies in Mycology 73, 115-180.

White JF, Belanger F, Meyer W, Sullivam RF, Bischoff JF, Lewis EA. 2002 Clavicipitalean fungal epibionts and endophytes-development of symbiotic interactions with plants. Symbiosis 33, 201-213.

Xia X, Lie TK, Qian X, Zheng Z, Huang Y, Shen Y. 2011 - Species Diversity, Distribution, and Genetic Structure of Endophytic and Epiphytic Trichoderma Associated with Banana Roots. Microbial Ecology 61, 619-625.

Zeng G-M, Shi J-G, Yuan X-Z, Liu J, Zhang Z-B, Huang G-H, Li J-B, Xi B-D, Liu H-L. 2006 Effects of Tween 80 and rhamnolipid on the extracellular enzymes of Penicillium simplicissimum isolated from compost. Enzyme and Microbial Technology 7, 1451-1456.

Zhang D, Ge H, Zou J, Tao X, Chen R, Dai J. 2014 - Perioconianone A, a new 6/6/6 carbocyclic sesquiterpenoid from endophytic fungus Periconia sp. with neural anti-inflammatory activity. Organic Letters, doi: 10.1021/o1500197x

Zhang Q, Wei X, Wang J. 2012 - Phillyrin produced by Colletotrichum gloeosporioides, an endophytic fungus isolated from Forsythia suspense. Fitoterapia 83, 1500-1505.

Zhao JP, Lu Q, Liang J, Decock C, Zhang XY. 2010 - Lasiodiplodia pseudotheobromae, a new record of pathogenic fungus from some subtropical and tropical trees in southern China. Cryptogamie Mycologie 31, 431-439. 